\title{
FORA DA ESTANTE: QUESTÕES DE ARQUIVO E DE PRESERVAÇÃO DA LITERATURA DIGITAL
}

\section{FUERA DE LA ESTANTE: CUESTIONES DE ARCHIVO Y PRESERVACIÓN DE LA LITERATURA DIGITAL}

\section{OFF THE SHELF: ISSUES OF ARCHIVING AND PRESERVING DIGITAL LITERATURE}

\author{
Rejane C. Rocha \\ Universidade Federal de São Carlos \\ rejane@ufscar.br
}

\begin{abstract}
Resumo:
Este artigo dedica-se a refletir a respeito do arquivo e da preservação da literatura digital. Para isso, percorre discussões relativas ao estatuto da efemeridade da cultura digital e de como ele se confronta com as especificidades do literário, que coloca em xeque iniciativas como a manutenção, a emulação, a adaptação e a recriação de obras, estratégias museográficas voltadas à produção artística em mídia variável. Como conclusão, propõe a ideia de "anarquivo", conceito mais condizente com as características da arte e da literatura do tempo presente. As reflexões aqui apresentadas são resultado do desenvolvimento do Projeto de Pesquisa (CNPq) "Repositório da Literatura Digital Brasileira".
\end{abstract}

Palavras-chave: literatura digital, arquivo, preservação.

\section{Resumen:}

Este artículo propone reflexiones sobre el archivamiento y la preservación de la literatura digital. Para eso, hace un recorrido por las discusiones relacionadas al estatuto de la fugacidad de la cultura digital y la manera como él se confronta con las especificidades del literario, que pone en jaque iniciativas como la manutención, la emulación, la adaptación y la recreación, estrategias museográficas utilizadas por la producción artística hecha en mídias variables. Al fin, propone la idea de "anarchivo", concepto más próximo de las características del arte y de la literatura de nuestro tiempo. Las reflexiones acá presentadas son resultado del desarrollo del proyecto de investigación subsidiado por CNPq (Consejo Nacional de Investigación) "Repositório da Literatura Digital Brasileira".

Palabras-clave: literatura digital, archivo, preservación.

\begin{abstract}
:
This article is dedicated to reflect on the archive and the preservation of digital literature. For this, it goes through discussions related to the status of the ephemerality of digital culture and how it confronts the specifics of the literary, which puts in check initiatives such as the maintenance, emulation, adaptation and recreation of works, museographic strategies aimed at production artistic in variable media. As a conclusion, he proposes the
\end{abstract}


idea of "anarchist", a concept more consistent with the characteristics of art and literature of the present time. The reflections presented here are the result of the development of the Research Project (CNPq) "Repositório da Literatura Brasileira Brasileira".

Keywords: digital literature, archive, preservation-

Recibido: 30 de abril de 2021

Aceptado: 16 de junio de 2021

\section{Literatura digital e a dialética da permanência e da efemeridade}

As muitas definições de literatura digital que se produziram ao longo das últimas duas décadas apontam, invariavelmente, para a relação inextricável - de resto já observável no sintagma "literatura digital" - entre a mobilização poética da linguagem verbal, que se inscreve no interior da longa tradição do que a sociedade ocidental denominou como literatura, e a mobilização dos códigos digitais, estes deslocados de sua produtividade técnica, desprogramados em sua função original para, então, assumir e produzir efeitos estéticos. O movimento, que pode ser lido em termos de uma negociação, é, então, de uma mútua contaminação e, nesse caso, desestabilização: de um lado, a literatura - aqui compreendida em termos de sistema (Zohar), não somente de produto -, inserida no contexto digital e fazendo uso dos códigos e dos meios digitais para construir a sua expressividade, sofre desestabilizações nas distintas esferas de sua existência: na linguagem de seus produtos, na relação que estabelece com os seus leitores, no lugar que ocupa na sociedade, na metalinguagem que, ao longo dos séculos, constituiu os seus contornos, descreveu seus mecanismos, estabeleceu seu valor; de outro lado, o código informático - e também as plataformas digitais -, demovidos de sua produtividade técnico-informacional, hackeados em sua função primeira, prevista pela sociedade tecnicista-capitalista, são contaminados pelo impulso estético e tornam-se componentes em laboratórios de experimentações expressivas as mais diversas.

Nesse ínterim nem literatura, nem códigos e meios continuam os mesmos, e não podem ser compreendidos em uma relação hierárquica de servidão que frequentemente a leitura crítica sobre a literatura pressupõe, quando da discussão a respeito dos seus “suportes”; uma discussão que pressupõe a preexistência da mensagem literária que seria, 
depois, alocada em dada materialidade. Na contramão do que Roger Chartier já identificou como uma desmaterialização da literatura, assumo, aqui, a perspectiva de que a compreensão - e também o arquivo e a preservação da literatura digital - deve partir dessa relação inextricável entre literatura e digitalidade, de modo que já não sejam apreendidos dois fenômenos (a literatura $+\mathrm{o}$ digital), mas apenas um, a literatura digital, mesmo que essa complexidade acarrete dificuldades ainda insolúveis para a sua apreensão crítica e para a sua preservação para as futuras gerações.

Assumindo esse pressuposto, proponho um exercício inicial de pensar de que maneira as especificidades das mídias digitais - descritas como "princípios" por Lev Manovich - motivam alguns dos traços característicos da literatura digital, seja em termos da constituição de sua linguagem, seja em termos do desenvolvimento de paradigmas que marcam essa produção.

Lev Manovich (63) afirma que os meios se tornam novos ao serem traduzidos em dados numéricos no computador, que deixa, então, de ser apenas um dispositivo de comunicação e assume o papel de "processador de meios". Tendo isso em vista, enumera e descreve os princípios dos novos meios: representação numérica, modularidade, automatização, variabilidade e transcodificação. A apreensão e compreensão desses princípios, em seu conjunto, pode apontar para condições de contorno muito específicas da literatura, em um contexto de digitalização, quando dados os mais variados passam a ser representados numericamente. A programabilidade dos novos meios, caracterizada tanto pela representação matemática da informação quanto pela sua manipulação algorítmica, possibilita que essa informação seja dividida em partes discretas que, assim, podem ser manipuladas, desmontadas e remontadas, gerando novas informações, atendendo e motivando, ao mesmo tempo, o anseio pela personalização característico da sociedade pósindustrial.

Em termos objetivos, e pensando de que maneira isso pode ser observado no caso específico da literatura, posso apontar dois exemplos, insuficientes para descrever conclusivamente o fenômeno, mas suficientes para ilustrar o processo, e a maneira como ele se faz sentir tanto no nível da especificidade formal dos objetos, quanto no que diz respeito a certa postura mais ou menos difusa de produtores e consumidores. 
O primeiro exemplo é o da multimodalidade, uma das características mais paradigmáticas da literatura digital e um traço muito importante da literatura digital brasileira, especificamente ${ }^{1}$. A convivência, nos objetos literários digitais, de distintas linguagens, como matéria verbal, som, imagem e movimento, que requerem a mobilização, por parte do leitor, de diferentes modalidades perceptivas (Lévy) só é possível graças ao fato de que essas diferentes linguagens se tornaram, no contexto das novas mídias, dados programáveis, virtuais, passíveis de serem decompostos recompostos e atualizados de maneira recorrente e personalizada pelo produtor e pelo consumidor ${ }^{2}$.

A mesma programabilidade, que resulta em modularidade e variabilidade, no caso da multimodalidade, é expressão e condicionante do que Jean Klucinskas e Walter Moser chamaram de "estética da reciclagem". Nesse caso, as possibilidades abertas pela conversão de qualquer produto cultural em elementos discretos que podem ser decompostos e recompostos de distintas maneiras, por qualquer um que tenha meios para fazê-lo - e desde a popularização dos computadores pessoais e, mais recentemente, com a web 2.0 e a ampliação da cultura de software, cada vez mais pessoas têm esses meios -, levam ao paroxismo as possibilidades de apropriação que, de resto, sempre foi um gesto artístico mais ou menos relevante ao longo de toda a história da arte ocidental. A reciclagem, como especificidade estética, mas também, como opção ética, desestabiliza os paradigmas culturais vigentes ao longo de séculos:

Generalizando injuriosamente, poder-se-ia pois afirmar que um paradigma estético de produção artística está em vias de deixar o espaço cultural. Esse paradigma pode ser mais bem definido pela tríade conceitual de novidade, originalidade e autenticidade. Esses três termos eram investidos de valor positivo. O novo paradigma que invade pouco a pouco o espaço cultural apóia-se em outra tríade, na qual a cópia, a reciclagem e a seriação podem ser identificadas como as características cardeais. (Klucinskas e Moser 34)

\footnotetext{
${ }^{1}$ Essa informação é resultante dos dados levantados pela pesquisa (IC/CNPq) Literatura Digital Brasileira: cartografia da produção crítica, em que Gabriela Gritti estudou a fortuna crítica das obras mapeadas pelo Projeto (CNPq) Repositório da Literatura Digital Brasileira e identificou quais os termos e conceitos mais empregados pelos estudiosos brasileiros da literatura digital brasileira. Mais informações sobre a pesquisa e sobre o projeto em https://www.observatorioldigital.ufscar.br/

2 O uso de "produtor", ao invés de autor e "consumidor", ao invés de leitor está em consonância com a terminologia empregada por Itamar Even-Zohar (2017) na sua discussão sobre o sistema literário. Acredito que esses termos, menos impregnados dos sentidos que a longa tradição da literatura impressa lhes imprimiu, podem ser úteis na descrição e compreensão da literatura digital.
} 
Com os autores, chamo a atenção para o fato de que tal mudança de paradigma não é ampla nem irrestrita, e que não se trata da substituição automática do tripé novidade, originalidade e autenticidade pelo de cópia, reciclagem, seriação. Trata-se de complexas negociações entre distintos atores da cena cultural, uns mais dispostos a arcar com as consequências dessa mudança de paradigmas - talvez produtores e consumidores estejam mais abertos a ela -, outros rejeitando-a de saída, por diferentes motivos - pensemos em como essa mudança afetaria, por exemplo, o funcionamento do mercado e como ela impactaria as bases da instituição. É ainda importante sublinhar que a reciclagem cultural, na perspectiva dos autores, não está restrita à literatura digital, mas a qualquer produto cultural, digital ou não, que se insere nesse contexto que poderíamos designar de contemporaneidade digital.

Uma aporia caracteriza a literatura digital - e talvez seja justamente por ela que é necessário usar essas palavras juntas e não advogar pelo uso apenas de "literatura": as possibilidades técnicas abertas pela programabilidade dos meios e a maneira como as obras literárias digitais se valem dessas possibilidades como componentes de sua fatura estética as inscrevem em uma temporalidade que não é, necessariamente ou exclusivamente, a da literatura, mas sim a dos dispositivos, hardwares, softwares, plataformas que compõem esses objetos literários digitais; uma temporalidade que é a da produção técnico-capitalista de bens de consumo. Embora se possam lembrar de experimentos literários em que a efemeridade era a base da sua proposta estética, tais experimentos normalmente a mobilizaram como recurso de provocação às bases culturais ocidentais - penso, sobretudo, no Dada - em um gesto que, paradoxalmente, contribuiu para a sua inserção nessas bases. A literatura, compreendida como sistema, pressupõe a temporalidade longa: o tempo da criação da obra, da sua fruição, da sua inserção em circuitos de legitimação e, por fim, da sua transformação em repertório que vai estimular outras criações, provocar outras leituras e, assim, sucessivamente.

A insolubilidade da aporia talvez possa ser lida como uma dialética da permanência e da efemeridade, algo que pode ser observado nas obras, na atitude de seus criadores, na maneira como se dá o seu funcionamento como sistema; mas isso talvez seja assunto para outro artigo. Para a discussão que proponho aqui, é importante ter em mente a diferença 
entre a efemeridade como recurso artístico e/ou como fim a ser alcançado pela obra, ou seja, como poética, e a efemeridade que é resultado das características sociotécnicas da tecnologia digital no interior da sociedade capitalista, ou seja, como consequência, raramente desejada ${ }^{3}$. Em um e outro caso é necessário preservar essas obras do desaparecimento

\section{Arquivo e preservação da literatura digital brasileira: estado da arte}

Para preservar é necessário, antes, conhecer. O que à primeira vista parece bastante óbvio, no que diz respeito à literatura digital ganha contornos específicos. Isso porque o conhecer, aqui, se amplia: vai dos objetos literários, em sua singularidade, aos contornos ainda indefinidos de um tipo de literatura emergente e que não possui plenamente estabelecidos metalinguagem e parâmetros de avaliação e de legitimação; a dificuldade é redobrada quando pensamos especificamente no caso brasileiro, já que o desconhecimento da nossa produção, em seu conjunto, dificulta uma leitura que leve em conta as suas especificidades e impede a formulação daqueles parâmetros de avaliação e de legitimação, atentos aos contornos da nossa produção.

Disso se depreende a primeira grande dificuldade - entre outras, que não abordarei aqui, dados os limites deste artigo -, enfrentada no início do processo de organização do arquivo que o Projeto $(\mathrm{CNPq})$ Repositório da Literatura Digital Brasileira ${ }^{4}$ está construindo. O mapeamento das obras, vencida a etapa de compilar aquelas que já fazem parte do que se esboça como uma história da literatura digital brasileira ${ }^{5}$, pressupunha não apenas a pesquisa para encontrá-las, mas também - e sobretudo - uma constante confrontação delas com os limites impostos pela taxonomia com a qual a equipe do projeto, em parceria com a equipe do projeto Cartografía crítica de la literatura digital

\footnotetext{
${ }^{3}$ Essa reflexão é feita por Pablo Gobira (2015) em texto que discute a preservação de obras de arte digitais.

4 Projeto modalidade APq (Número:405609/2018-3; Vigência: 18/02/2019 a 28/02/2022), sob minha coordenação, cujos objetivos são mapear, organizar, arquivar e preservar a literatura digital brasileira. No site https://www.observatorioldigital.ufscar.br/ podem-se obter informações sobre o andamento do projeto, seus resultados parciais, as metodologias empregadas e as pesquisas derivadas. Doravante me referirei ao projeto como Projeto RLDB.

${ }^{5}$ A primeira etapa de mapeamento dedicou-se às obras que já constavam de antologias, repositórios e/ou já tinham sido compiladas por outras iniciativas de reunião da literatura digital brasileira.
} 
latinoamericana, decidiu trabalhar, elaborada pelo Consortium on Electronic Literature (CELL Project):

No sentido mais básico, as taxonomias são uma forma de agrupar coisas. As taxonomias são projetadas para ser um sistema de organização de conteúdo online que atua como uma camada de semantização destinada a qualificar dados. Eles são complementares ao mecanismo de pesquisa e permitem uma pesquisa facetada. $O$ conteúdo recuperado pelo mecanismo de busca pode então ser filtrado pelo sistema de classificação concebido para o CELL.

Como resultado, as categorias usadas no CELL surgiram das próprias obras da literatura eletrônica: desde o final da década de 1990, os parceiros do projeto CELL etiquetaram o conteúdo usando termos para descrever um objeto em evolução - o trabalho da literatura eletrônica. O objetivo é reorganizar a marcação original em categorias mais neutras e descritivas que podem ser usadas em todo o campo. ${ }^{6}$ (grifos meus; tradução minha)

O movimento invariável era o de descrever as obras pela taxonomia para, depois, compreender o quanto elas, nas suas especificidades, esgarçavam esses limites. E nesse sentido, a metáfora usada por Katherine Hayles, sobre a literatura eletrônica, "monstro esperançoso", assumia significados muito concretos. O embate entre a regularidade e a homogeneidade das categorias taxonômicas e as arestas evidenciadas pela análise das obras específicas, normal em qualquer processo de mapeamento e arquivamento, ganhava uma camada a mais de complexidade quando identificávamos que muitas daquelas categorias estavam distantes da realidade técnico-poética da literatura digital brasileira ${ }^{7}$.

A previsão de categorias taxonômicas é um importante mecanismo de institucionalização e reconhecimento de dada produção cultural e artística; isso porque elas ajudam a estabelecer os limites de certos objetos culturais e, fazendo isso, indicam também

\footnotetext{
${ }^{6}$ No original em inglês: In the most basic sense, taxonomies are a way of grouping things. Taxonomies are designed to be an online content organization system that acts as an underlayer of semantization meant to qualify data. They are complementary to the search engine and enable a faceted search. Content retrieved by the search engine can then be filtered by the classification system conceived for the CELL. As a result, the categories used in CELL emerged from the works of electronic literature themselves: since the late 1990s, the partners of the CELL project have tagged content using terms to describe an evolving object - the work of electronic literature. The goal is to reorganize the original tagging into more neutral and descriptive categories that could be used throughout the field. Disponível em: http://cellproject.net

${ }^{7}$ As instituições e grupos que compõem o CELL Project e que, portanto, dão os subsídios para a formulação da sua taxonomia, estão listados na página do projeto em http://cellproject.net/members. Ressalte-se que não há nenhum grupo de pesquisa ou instituição latino-americana entre os membros do CELL Project.
} 
os limites de um campo. Se as categorias taxonômicas, por um lado, buscam "refletir o estado atual da pesquisa na área”, em um movimento indutivo que está previsto pelo CELL Project, por outro lado elas estabelecem vetores de compreensão da literatura digital que, como consequência, se convertem em paradigmas de avaliação. Ao longo das etapas de mapeamento das obras literárias digitais brasileiras, compreender isso garantiu que não se convertessem as categorias taxonômicas, sobretudo aquelas relacionadas a uma poética das obras, em expectativas e critérios de seleção. De maneira objetiva, isso significa dizer que foi importante ter em mente as especificidades da literatura digital brasileira, que, vale lembrar, no início do mapeamento eram, também, bastante incertas para a equipe do Projeto RLDB.

Evidentemente, partir das especificidades da literatura digital brasileira não foi tarefa fácil. Afinal, quais eram essas especificidades? Talvez o seu adequado delineamento só seja possível a partir da observância e análise do arquivo que está em construção, tarefa para pesquisas futuras e para outros pesquisadores. O que sabíamos e o que orientou as atividades de mapeamento era que tais especificidades diziam respeito à história da literatura digital no Brasil, à relação dessa literatura, emergente, com a nossa tradição literária e artística, a sua inserção nos circuitos da materialidade técnica, tal qual ela se configura no Brasil, um país da periferia do desenvolvimento tecnológico, a sua relação com o nosso contexto sócio-cultural-tecnológico, enfim.

A descrição de uma obra literária digital a partir de categorias taxonômicas pode ser considerada um primeiro passo para o seu arquivamento e preservação - ou, pelo menos, esse foi o caminho percorrido no caso do Projeto RLDB, especificamente. O objetivo, aqui, é o de reunir o maior número possível de informações a respeito da materialidade da obra, seu contexto histórico/técnico de produção, como ela chega ao leitor e como este interage com ela, os recursos estéticos que mobiliza, seu pertencimento a dado gênero, etc. À descrição unem-se outras estratégias de documentação: a captura de imagens, a gravação de vídeos de navegação simulada, a entrevista com os autores, a recuperação e reunião de fortuna crítica sobre cada obra. Além disso, evidentemente, o arquivamento de códigosfonte e arquivos executáveis é estratégia a que recorremos, embora reconheçamos que, atualmente, são estratégias inócuas no que diz respeito a possibilitar o pleno acesso a essas obras, no futuro, dado o fato de que elas requerem, em alguns casos, para serem executadas, 
softwares que não estão mais disponíveis para a maioria dos leitores, usuários não especializados da tecnologia.

A questão que se coloca - e que está no horizonte, também, de outras pesquisas e outros pesquisadores (Gobira; Magalhães e Beiguelman) que se dedicam a refletir sobre as possibilidades, viabilidade e limitações da construção de arquivos de arte tecnológica - diz respeito não só ao que arquivar e preservar, mas também a como fazê-lo. Isso porque na arte e na literatura que se produzem a partir das mídias digitais

o contexto está intimamente conectado ao conteúdo. A dinâmica da web traz elementos informacionais por meio de diferentes fontes que são combinadas apenas quando o participante ativa a tela. Os comandos do monitor estão conectados ao código estruturado e programado do site, os quais estão disponíveis por meio de um servidor local conectado a um território globalmente acessível [...] Por intermédio de meios de transferência e transmissão, o contexto também pode tornar-se conteúdo (Lovejoy, cit. por Beiguelman 13).

No que diz respeito à literatura digital, a indissociabilidade entre matéria verbal e não verbal, entre protocolos de leitura herdados da cultura impressa e aqueles exigidos pelos objetos multimodais/hipertextuais/hipermidiáticos, "ergódicos", na terminologia proposta por Espen Aarseth tornam complexos tanto o arquivamento quanto a preservação das obras. Para além da obsolescência dos softwares em que as obras são construídas, problema óbvio, mas não menos importante, outras questões se colocam e exigem estratégias e decisões que não são consensuais nem genéricas. Alguns exemplos, a título de mera ilustração, podem dar a medida dessa complexidade, ainda que não prevejam a totalidade dos desafios que a construção do repositório deverá enfrentar.

Os procedimentos hipertextuais e hipermidiáticos que pressupõem que o leitor/interator selecione o seu percurso de leitura e que navegue (interna ou externamente à obra) para que a história (no caso das narrativas hipertextuais) avance, exemplifica uma dificuldade óbvia para o arquivamento e preservação dessas obras. Aqui, a materialidade hipertextual, que pode ser documentada a partir da ficha de catalogação que prevê o recurso como categoria taxonômica, só se realiza plenamente a partir da ação do leitor, que atualiza um percurso narrativo que, antes disso, é apenas virtual. Outras obras, não necessariamente hipertextuais ou hipermidiáticas, pressupõem a agência (Murray) do leitor para a sua 
constituição: alteração de elementos, inserção e/ou supressão de dados, entre outras coisas, são as ações requisitadas para que o que existe em potencial possa ser atualizado. A documentação dessas obras por meio, por exemplo, de vídeos de navegação simulada, dá conta do procedimento, mas não dos significados que se constroem no processo de navegação, exemplo paradigmático daquilo que Manovich identifica como um dos princípios dos novos meios, a variabilidade. Ao fim e ao cabo, o que se documenta é uma possibilidade de atualização da obra em potencial, entre tantas outras possíveis; o que não pode ser documentado a contento é o contexto midiático que pressupõe a variabilidade como princípio fundamental de obras como essas.

As obras digitais constituídas pelas plataformas de redes sociais apresentam outra camada de complexidade para o seu arquivamento e preservação. Novelas no Twitter, romances no Facebook, experimentos no Instagram, enfrentam, de saída, questões relativas às especificidades de apresentação e de circulação de conteúdo relativas às configurações algorítmicas dessas plataformas: a experiência de leitura, e portanto, os significados que emergem da leitura processual dessas obras - aquela que o leitor faz, ao ter acesso, aos poucos, ao conteúdo postado paulatinamente pelo autor, ao longo de dado período de tempo - não são os mesmos do leitor que tem acesso à obra na sua totalidade, depois de concluída. Isso porque o contexto de apreensão dessas obras é diferente, em um e outro caso; e contexto se refere, aqui, ao entorno de uma postagem, à atitude do leitor que é obrigado a suspender os gestos corriqueiros no interior de uma plataforma para ler literatura ${ }^{8}$, etc. Ainda que se ignore esse primeiro obstáculo, pela sua aparente insolubilidade, a dificuldade recai sobre a dificuldade de preservar, justamente, o que tenho postulado ${ }^{9}$ como a característica que distingue a literatura digital produzida nas redes sociais daquela que usa as redes como veículo de publicação e de divulgação e que diz respeito às maneiras pelas quais o funcionamento dessas redes possibilitam uma alteração dos gêneros literários tais quais os conhecemos.

A questão é que ainda não há, consolidadas, estratégias nem para documentar, nem para arquivar e preservar seja o uso que os autores fazem dessas funcionalidades, seja os

\footnotetext{
${ }^{8}$ Em reflexão sobre isso, Reinaldo Laddaga (24), citando Wittig pondera que "a literatura agora aparece na mesma tela que se usa tanto para uma mais íntima mensagem como para o trabalho mais alienante. Portanto, nenhum texto em rede pode solicitar um espaço próprio para si. A literatura não se distancia das tarefas cotidianas, não há lugar para um "espaço literário".

${ }^{9}$ Consultar o verbete "Literatura digital" (Rocha).
} 
resultados que alcançaram em suas obras. Como arquivar e garantir a preservação disso tudo? E a questão pode ser ainda mais chã, embora não menos complexa: como arquivar e preservar essas obras, em sua totalidade, quando essas plataformas forem simplesmente descontinuadas?

O que se percebe, então, é que a própria noção de contexto - muito cara para as discussões sobre preservação de obras de arte tecnológicas e de net art - é colocada em questão, já que

Ela estava clara, ao que parece, para as práticas artísticas e de pesquisa, quando consideramos as metodologias de trabalho e teorias da história da arte como disciplina acadêmica. Para o historiador de arte, era evidentemente essencial compreender o contexto de produção de seu objeto de estudo - a obra . Porém sua materialidade, seus aspectos físicos parecem ter sido por muito tempo considerados elementos permanentes da obra, cuja descrição era neutra, na medida em que não poderia alterar substancialmente sua interpretação (Magalhães).

Parece que a questão que atormenta aqueles que se dedicam a arquivar, preservar e, mesmo, colecionar as obras de arte - e também a literatura - produzida em mídias variáveis, é que a própria noção de contexto é colocada em xeque, uma vez que também instável, dado o fato de que o meio digital, como já explicado em outro momento, tem como princípio a variabilidade, ou seja, "o contexto não só interfere na recepção da obra como também modeliza [a sua] recepção" (Beiguelman s/p). A reflexão de Arlindo Machado, dedicada a discutir as especificidades do hipertexto, mas que pode ser estendida para a produção literária digital, como um todo, coloca em questão, também, a própria noção de obra, como grosso modo, a compreendeu a modernidade e, por conseguinte, dá mais uma medida das dificuldades em arquivar e preservar as obras digitais:

A disponibilidade instantânea de todas as possibilidades articulatórias do texto verbo-audiovisual favorece uma arte combinatória, uma arte potencial, em que, em vez de se ter uma "obra" acabada, tem-se apenas seus elementos e suas leis de permutação definidas por um algoritmo combinatório. A "obra" agora se realiza exclusivamente no ato de leitura e em cada um desses atos ela assume uma forma diferente, embora, no limite, inscrita no potencial dado pelo algoritmo. (Machado 146) 
Se a conservação da arte computacional, especificamente da literatura digital que se constroi em rede, pressupõe não apenas "pesquisa técnica contextual e material", [mas também] análises e conhecimento sobre seu caráter performativo e sobre como ela é experimentada" (Dekker s/p), ficam explícitas as limitações da documentação como estratégia efetiva de arquivo e preservação.

Um exemplo pode não apenas tornar mais concreta a discussão, como também ajudar a compreender a especificidade da literatura digital no interior das reflexões sobre arquivo e preservação da arte digital.

Poemas de brinquedo é uma obra da literatura digital brasileira que foi compilada pelo Projeto Repositório no início das atividades de mapeamento das obras, no primeiro ano de desenvolvimento do projeto. Trata-se de obra publicada em 2016 de autoria de Álvaro Andrade Garcia, com a colaboração de Renata Farhat Borges, Ricardo Aleixo, Márcio Koprowski, Joacélio Batista, Matheus Braga, Valéria Braga e Lucas Junqueira, este último responsável pela criação do software Managana, gratuito e aberto, no qual outros objetos literários digitais foram programados. A obra foi mapeada e teve a sua descrição taxonômica produzida pela equipe do Projeto RLDB em outubro de 2018, no primeiro ano da pesquisa; na ficha de catalogação, constam informações contextuais sobre a obra: data de produção, site em que está disponível, o que se exige, em termos materiais (dispositivos) para que ela funcione e para que seja acessada pelos leitores, quais procedimentos de leitura (no sentido ampliado do termo) estão envolvidos na sua apreensão. Em 2018, quando a obra foi mapeada pela primeira vez, acessava-se a obra a partir da página do software em que ela foi desenvolvida e essa página reunia, ainda, outras obras literárias digitais produzidas com o Managana. Hoje, em outubro de 2020, ao seguir o link transcrito na ficha de catalogação da obra, surge a seguinte mensagem: 
Fonte: Site Managana (www.managana.org.br)

\section{Oops... you'll need to enable the Flash Player plugin to run Managana ;-)}

You need to enable the Adobe Flash Player to run Managana: just click here to allow it

\section{Opa... você precisa ativar o Flash Player para acessar o Managana ;-)}

Você precisa habilitar o Adobe Flash Player para conferir o Managana: basta clicar aqui e autorizar a abertura do plugin

Fig. 1: Captura de tela site Managana

Não quero abordar, aqui, em detalhes, a situação do Flash $^{10}$, programa no qual muitas das obras literárias digitais brasileiras foram programadas e que deixará de ter compatibilidade em todos os navegadores web a partir de dezembro de 2020. De qualquer maneira, até dezembro de 2020, se o leitor tivesse instalado na sua máquina o Adobe Flash Player e se ele desse as permissões necessárias, ele ainda podia acessar a obra. Atualmente, a única maneira de acessar a obra é executar o seu arquivo localmente em um máquina que ainda tenha o programa instalado ou, então, a partir de emuladores que têm sido disponibilizados, inclusive pela Adobe.

Antevendo o problema da incompatibilidade do Flash, Álvaro Andrade Garcia remodela o seu site pessoal, o Ateliê Ciclope, antes também programado em Flash, para uma versão em Wordpress, o que, segundo o autor, o altera profundamente, no que diz respeito às possibilidades de interação. Em duas postagens, a primeira de janeiro de $2020 \mathrm{e}$ a segunda, de julho de 2020, reflete sobre isso e lamenta que conteúdos de outras obras já estejam indisponíveis:

\footnotetext{
10 Sobre a descontinuação do suporte ao Adobe, acesse: https://www.blog.google/products/chrome/sayinggoodbye-flash-chrome/
} 


\section{HOME \\ sítio de imaginação}

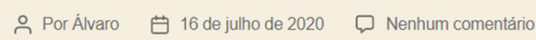

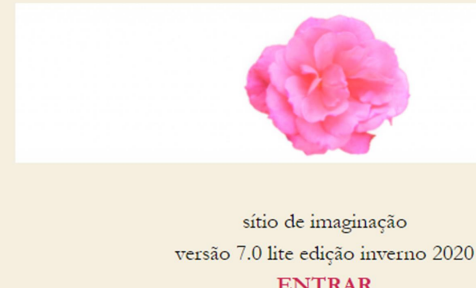

ENTRAR

Em tempos de pandemia, fascismo e brutalidade crescente na

sociedade e concentração no mundo digital, com o esvaziamento da

wwww pelas 'redes sociais' corporativas, mantemos nossa resiliência e

continuamos on line. Viva a Poesia.

BLOGUE - CULTURA DIGITAL, POIESIS E WORK IN PROGRESS

\section{holocausto}

$\curvearrowleft$ Por Álvaro $\boxminus 1$ de janeiro de 2020 ๑ Nenhum comentário

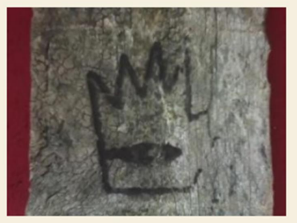

Em 2020 o bloqueio ao software Flash e seus derivados livres na internet e nos apps nos obrigou a tirar do ar o Sítio de Imaginação, o Sertão

Vivo e os conteúdos do Cidades Históricas.

Managana, o software livre do ateliê não funciona mais em bronsers e em apps para Android e Ios. Somente em versão local para Windows.

Está no ar uma versão lite do Sítio de Imaginação para retornar com seus audiovisuais para o mundo da web e apps, mesmo tendo que sacrificar a interação. É preferivel ao ostracismo.

Fig. 2: Captura de tela do site Ateliê Ciclope 
Hoje, ao clicar em ENTRAR, no primeiro post de que capturamos a imagem, há uma documentação muito relevante, produzida pelo autor, sobre o software, da sua criação até a sua iminente inacessibilidade. Nessa página, a aba "Fluxos" conduz o leitor à página dedicada a Poemas de Brinquedo. Nela, há informações sobre a obra digital e a sua versão impressa, sobre o software e o aplicativo na qual foi construída e um link para que o leitor aceda ao seu arquivo executável, que deve ser instalado localmente, em ambiente Windows, em computador que possua a versão compatível do Adobe Flash Player.

Quero chamar a atenção para o quanto essa longa, mas necessária descrição do contexto da obra aponta para uma profunda alteração nas informações que constam na ficha de catalogação produzida em outubro de 2020. Naquela ocasião, para ter acesso à obra bastava clicar em um link; quando este texto foi escrito, era necessário que o leitor baixasse um programa (caso ele ainda não o tivesse em sua máquina) e desse uma permissão para que ele funcionasse ou baixasse um arquivo executável em ambiente Windows e com versão compatível do software proprietário capaz de fazer a leitura do Flash. Hoje (março de 2021), é necessário baixar o arquivo executável da obra, baixar um emulador e executar a obra a partir dele - sem garantia de que a obra possa ser lida exatamente como era quando foi criada e publicada. Evidentemente, o contexto mudou; e se concordarmos com Lovejoy, citado por Beiguelman (2014), o conteúdo da obra também - e continuará mudando. As informações que compõem a documentação da obra devem registrar o histórico dessa mudança? Devem ser simplesmente atualizadas? As respostas a essas questões estão em aberto, ainda.

\section{Contrabandos metodológicos}

É do campo das artes tecnológicas que vêm as principais contribuições para as tentativas de arquivar e preservar as obras que se valem das ferramentas digitais para as suas proposições estéticas. Como se pôde constatar pelo percurso da obra Poemas de Brinquedo, que descrevi antes, a produção documental da obra, com vistas a reunir informações sobre ela e arquivá-la adequadamente - bem como disponibilizá-la para acesso - anda de par com o desafio de preservá-la para que leitores possam acessá-la ao longo do maior período de tempo possível. Embora concordemos com Giselle Beiguelman, quando a 
autora afirma que, no caso da arte digital não se trata de e se a obra se tornar indisponível, mas quando isso acontecerá, é nesse quando que, me parece, podemos tentar operar para que ele seja o mais tarde possível.

Como procurei demonstrar, no caso da literatura digital - assim como no caso da arte digital - o contexto é variável e efêmero, seja por causa da configuração das plataformas, seja pela obsolescência ou incompatibilidades dos softwares em que as obras são produzidas. Ainda que se admita que a documentação sobre as obras não substitui as obras, é inegável que se trata de um recurso importante para a sua preservação, em um contexto em que o que se coloca é a necessidade premente de "estratégias de preservação elaboradas em camadas e com capacidade de admitir fragmentos e vestígios, processos de emulação, recriação e remontagem" (Rinehart cit. por Beiguelman s/p), ou ainda, em um contexto em que "o paradigma da conservação relacionado à retórica da autenticidade e à cultura de sustentabilidade material atingiu seus limites ao enfrentar os mundos de mídias transicionais e suas "superações" e "travessias" para territórios novos e desconhecidos" (Hölling 46).

A minha intenção, no interior desse debate, é iniciar uma discussão sobre de que maneira as principais estratégias de preservação da arte em mídias variáveis podem contribuir para a preservação da literatura digital brasileira. A esta altura, acho necessário situar a discussão, ou seja, conduzi-la a partir de nosso contexto geográfico-técnico e cultural, uma vez que esses contornos é que podem nos dar a medida das possibilidades que efetivamente estão ao nosso alcance, no momento atual, em um país que se localiza na periferia do desenvolvimento tecnológico, que recém excluiu as Humanidades do que considera "áreas de pesquisa prioritárias", que tão pouco faz pela manutenção adequada de seus acervos museográficos e bibliográficos.

As principais estratégias para a preservação da arte em mídias variáveis, além da documentação, são a manutenção, a emulação, a adaptação e a recriação ${ }^{11}$. É importante sublinhar que a documentação é um primeiro passo a ser cumprido a fim de tornar possível qualquer uma das três outras estratégias, ou seja, pressupõe a reunião do maior número possível de informações técnico-poéticas e contextuais em geral - a despeito das

\footnotetext{
${ }^{11}$ Tais estratégias têm sido propostas, discutidas e normalizadas por instituições museológicas e de pesquisa de vários países europeus, além dos Estados Unidos. A esse respeito, ver Paul.
} 
dificuldades já expostas - sobre as obras, a fim de que elas possam ser arquivadas, preservadas e, quiçá, restauradas.

A manutenção requer que softwares e dispositivos sejam coletados e armazenados, a par das obras que nele se construíram; a emulação pressupõe a utilização de um novo dispositivo que coloque em funcionamento os programas de um dispositivo anterior, nos quais a obra a ser preservada foi concebida. A adaptação (ou migração) prevê que a obra, produzida em dado programa, obsoleto, seja reprogramada em uma nova linguagem, mantendo, na medida do possível, "o comportamento dos meios e os resultados finais" (Gobira et al 6). E a recriação, como se pode prever, trata de estratégias que reconfiguram a obra, pela reconfiguração de seus elementos - linguagem de programação, comportamento dos meios, interface, etc. - admitindo, no processo, alterações significativas, inclusive no que tange aos significados estéticos da obra.

Tais estratégias, inseridas no contexto contemporâneo, em que o arquivo

deve [...] ser entendido não apenas como um mero depósito de documentos, "representação" da obra "original", mas como um gesto que - por ser sempre lacunar e por não conseguir dar conta da obra na sua totalidade - abre espaço para o entendimento da obra dentro de múltiplas perspectivas como "um fazer" constante (Arantes 118)

faz-nos questionar o quanto documentação e emulação são estratégias afeitas a uma configuração estática de arquivo que, talvez, não seja mais viável na contemporaneidade digital, em que a instabilidade e a efemeridade dos meios torna sisífica as tarefas relacionadas à manutenção - seja de dispositivos, seja de linguagens de programação, seja dos resultados estético-poéticos de sua mobilização em obras literárias digitais. A manutenção e a emulação, importantes estratégias para que, por exemplo, obras de arte digitais possam continuar sendo expostas nos espaços museográficos, pouco pode contribuir para a preservação da literatura digital, uma vez que a experiência literária - aqui compreendida como o que resulta da articulação entre os seus espaços de inscrição material, modos específicos de circulação e protocolos de leitura/consumo -, que idealmente deveria ser preservada juntamente com a obra, não se dá em espaço expositivo. Muito embora obras e autores contemporâneos estejam nos colocando diante de um ponto de viragem e de alteração dessa experiência, digamos particular e individual de contato com 
a obra - alteração discutida e conceitualizada em termos de pós-autonomia (Ludmer) e inespecificidade (Garramuño) -, ela ainda é a norma da fruição literária. A manutenção de dispositivos e softwares e a emulação de programas requerem estratégias institucionais e coletivas que extrapolam, na maioria dos casos, a iniciativa individual de um leitor de literatura digital. Tais estratégias institucionais e coletivas transferiram a experiência de leitura para um espaço expositivo; ainda que ignorássemos o quanto isso é, atualmente, inviável na conjuntura brasileira, impõe-se a questão de que isso alteraria, também, a experiência de leitura que, como mencionamos anteriormente, retomando Beiguelman, Magalhães e Machado constitui também o contexto da obra literária digital.

Adaptação e recriação, parece-me, movem-se na direção de uma aceitação da inevitabilidade da perda do original - o que, de resto, como antes discutimos, em muito dialoga com os princípios dos novos meios e com a postura ideológica e estética daí decorrente, descrita em termos de "reciclagem" por Klucinskas e Moser. Nesse caso, não se trata mais, como no par anteriormente mencionado, de tentar replicar a obra tal qual ela foi concebida, estratégia inócua, dado o fato de que o contexto variável das mídias digitais, no caso da literatura, é irreplicável; ao invés disso, trata-se de assumir estratégias de arquivo e de conservação tão dinâmicas quanto as mídias em que as obras foram concebidas e o contexto que a sua circulação e a sua fruição delinearam. Trata-se, talvez, de construir não mais arquivos, mas "anarquivos" (Seligman-Silva 202) em que a manutenção e a emulação, gestos replicadores, cedam lugar à adaptação e à recriação, gestos criativos: o primeiro relacionado à experimentação criativa com softwares e dispositivos, o segundo, com poéticas e estéticas; um e outro operando na preservação das obras na medida em que as colocam em circulação no interior de atividades que são de leitura e de escrita, simultaneamente.

Há que se admitir, no entanto, que adaptação e recriação, embora muito insertas em um contexto da cultura contemporânea, que cada vez mais assume como valores "a cópia, a reciclagem e a seriação" (Klucinskas e Moser 34), esbarram em verdadeiros pilares que consolidaram o edifício literário ocidental, compreendido, aqui, como sistema, ou seja, como conjunto de fatores, atores e atividades que configuraram o literário ao longo da história, dada sua institucionalização e especificação no interior do campo cultural. Tais pilares, fundados na tradição da cultura impressa, estão relacionados a, por exemplo, o 
lugar e o papel ${ }^{12}$ fundamentais do autor na constituição da obra original. Autor, obra e originalidade articulam-se como conceitos essenciais para o delineamento do literário, em termos epistemológicos, teóricos e críticos, e para o seu funcionamento, no que diz respeito a sua inscrição material e a sua circulação como produto de cultura e de mercado.

O que se nos impõe, ao planejar o arquivo e a preservação da literatura digital, é a compreensão do entrelugar que assume essa produção: entre a tradição consolidada da literatura, sobre os pilares já mencionados, e as possibilidades colocadas a sua disposição pelos princípios dos novos meios que, como também já foi mencionado, alteram os seus contornos estéticos e éticos. Entre arquivo e anarquivo, as estratégias de preservação deveriam ser capazes de documentar justamente esse perfil aporético da literatura digital, talvez a sua principal característica hoje, quando cultura impressa e cultura digital convivem.

\section{REFERÊNCIAS}

Aarseth, Espen J. Cybertext: perspectives on ergodic literature. The Johns Hopkins University Press, 1997.

Arantes, Priscila. Relescrituras da arte contemporânea: história, arquivo e mídia. 1. ed., Sulina, 2015.

Beiguelman, Giselle. "Reinventar a memória é preciso". Magalhães e Beiguelman, p. 1233.

CELL Project. http://cellproject.net/. Acesso em 18 set. 2020.

Chartier, Roger. O que é um autor? Revisão de uma genealogia. EDUFSCar, 2012.

Dekker, Anne. "Os desafios da conservação da net art: aceitação da perda e da subjetividade". Magalhães e Beiguelman, p. 66-78.

Even-Zohar. Itamar. Polisistemas de cultura: un libro provisorio. Universidade de Telaviv, 2017.

Garcia, Álvaro Andrade. Blogue - cultura digital, poiesis e work in progress - ateliê ciclope - arte e publicação digital, https://www.ciclope.com.br/category/blognews. Acesso em 4 set. 2020

Garramuño, Florencia. Frutos estranhos: sobre a inespecificidade na estética contemporânea. Rocco, 2014.

Gobira, Pablo, org. A memória do digital: e outras questões de arte e museologia. EDUEMG, 2019.

---. "Por uma preservação integral da obra de arte digital: anotações sobre arte tecnológica". RDBCI: Revista Digital de Biblioteconomia e Ciência da Informação, v. 14, n. 3, 2016, p. 501-514

\footnotetext{
${ }^{12}$ Consultar, a esse respeito, o verbete "Autor" (Salgado, 2020).
} 
Gobira, Pablo et al. "Instabilidade digital: a preservação e a memória da arte digital no contexto contemporâneo". Encontro Internacional de Arte e Tecnologia, n. 13, 2015, p. 13.

Hayles, Katherine. Literatura eletrônica: novos horizontes para o literário. 1. ed., UPF Editora, 2009.

Hölling, Hanna. B. "Mídia transicional: permanência, recursividade e o paradigma da conservação". Gobira, A memória do digital, p. 37-50.

Klucinskas, Jean e Walter Moser. "A estética à prova da reciclagem cultural". Scripta, v. 11, n. 20, 2007.

Laddaga, Reinaldo. "Uma fronteira do texto público: literatura e meios eletrônicos". Literatura e mídia, organizado por Heidrun K. Olinto e Karl Erick Schollhammer. PUC/Loyola, 2002, p. 17-31.

Lévy, Pierre. Cibercultura. 2. ed., Editora 34, 2008.

Ludmer, Josefina. "Literaturas pós-autônomas". SOPRO 20: panfleto político-cultural, 2010, http://culturaebarbarie.org/sopro/n20.pdf. Acessado em 23 set. 2020.

Machado, Arlindo. Arte e Mídia. Zahar, 2007.

Managana. http://www.managana.org/editor/?community=sarria. Acesso em 8 out. 2020.

Manovich, Lev. El lenguaje de los nuevos medios de comunicación. Paidós, 2005.

Magalhães, Ana Gonçalves. "Considerações para uma análise histórico-crítica da catalogação de acervos artísticos". Magalhães e Beiguelman, p.34-45.

Magalhães, Ana Gonçalves e Giselle Beiguelman, org. Futuros possíveis: arte, museus e arquivos digitais. FAPESP/Itaú cultural/EDUSP/Peirópolis, 2014.

Murray, Janet. Hamlet no Holodeck. UNESP/Itaú Cultural, 1997.

Paul, Christiane. "Os museus no passado e no futuro do pós-digital: materiais, mediação, modelos". Gobira, A memória do digital, p. 51-68.

Rocha, Rejane. "Literatura Digital". Ribeiro et al., p. 80-84.

Ribeiro, Ana Elisa et al., org. Tarefas da Edição: pequena mediapédia. LED/Impressões de Minas, 2020, http://www.letras.bh.cefetmg.br/wp-content/uploads/sites/193/2019/ 10/Tarefas-da-Edic\%CC\%A7a\%CC\%83o-arquivo-digital-07-10-20.pdf.

Salgado, Luciana Salazar. "Autoria”. Ribeiro et al., p. 40-44.

Seligman-Silva, Márcio. "Posfácio: Arquivo e coleção ou uma borboleta chamada Miranda". Arantes, p. 197-210. 